\title{
MAKNA DAN SIMBOL TARI DEWA MEMANAH DALAM UPACARA ADAT ERAU DI KERATON KUTAI KARTANEGARA
}

\author{
Oleh \\ Auliana Rizka Luthfitasari \\ Pembimbing Tugas Akhir: \\ Dr. Rina Martiara, M.Hum dan Indah Nuraini, S.S.T, M. Hum \\ Jurusan Tari Fakultas Seni Pertunjukan Institut Seni Indonesia Yogyakarta \\ Alamat Email: aulianarizka@ gmail.com
}

\begin{abstract}
Ringkasan
Penelitian ini menganalisis makna dan simbol tari Dewa Memanah yang merupakan salah satu tari dalam ritual perayaan adat Erau Erau di Keraton Kutai Kartanegara. Tari Dewa Memanah merupakan tarian yang wajib ada dalam upacara ritual Bepelas dan ditarikan oleh seorang penari perempuan yang disebut Dewa Belian dengan properti sebuah busur dan anak panah yang ujungnya bercabang tujuh dan berapi.

Penelitian ini menggunakan metode kualitatif deskriptif, dengan pendekatan semiotika Pierce. Bagi Pierce tanda dan pemaknaan bukan merupakan sebuah struktur melainkan suatu proses yang berorientasi pada kemampuan berfikir yang mencakup kemampuan intelektual sampai pada kemampuan memecahkan masalah yang disebutnya semiosis. Proses semiosis ini melalui tiga tahap yaitu tahap pertama adalah penyerapan aspek representamen tanda melalui panca indra, kedua mengaitkan secara spontan dengan pengalaman dalam kognisi manusia yang memaknai representament itu (disebut object), dan ketiga menafsirkan object sesuai dengan keinginannya, tahap ketiga ini disebut interpretant.

Hasil dari penelitian ini adalah tari Dewa Memanah merupakan penggambaran seorang dewa yang sedang memanah dengan maksud untuk mengusir roh-roh jahat agar tercipta ketentraman, keselamatan, dan keamanan selama prosesi ritual Bepelas berlangsung.
\end{abstract}

Kata kunci: Tari Dewa Memanah, Erau, Kutai Kartanegara 


\begin{abstract}
This study aims to determine the meaning and symbol of the Dewa Memanah dance which is one of the rituals of Erau traditional celebrations. Therefore, the researcher tries to find the signs in the Dance of DewaMemanah then analyze it so that the meaning contained therein can be understood together.

This research uses descriptive qualitative method. The object of this research is the Dewa Memanah Dance in traditional ceremony of Erau in Keraton Kutai Kartanegara. Research subjects are traditional leaders, dancers, and Kutai tribe community. Data collection techniques used participatory observation, interview, and documentation methods. Data analysis techniques used data selection, data presentation and conclusion.

The result of the research is that the Dance of Dewa Memanah is a dance whichperformed by a female dancer called Dewa Belian by using a bow and arrows with seven branched ends. Dewa Belian surrounds the place of ceremony while swinging her bow and arrows up and down, followed by a bememang (spell reading) which asks the Gods to drive out demons and asks for peace, fertility, and prosperity for the people.
\end{abstract}

Keywords: Tari Dewa Memanah, Erau, Kutai Kartanegara 


\section{PENDAHULUAN}

Suku Kutai termasuk suku Melayu tua. Dahulunya suku ini bernama Kutai Adat Lawas. Suku Kutai Adat Lawas memiliki banyak adat-istiadat yang terus dipelihara hingga kini. Salah satunya adalah upacara adat Erau yang harus selalu mereka laksanakan pada waktu yang telah ditentukan sesuai kepercayaan mereka. Mereka percaya bahwa ada sumber kekuatan lain yang berasal dari dimensi berbeda di bumi ini. Kekuatan yang berasal dari para Dewa dan roh Leluhur. Oleh karena itu mereka sering mengadakan upacara yang bertujuan untuk kemakmuran dan keselamatan. Upacara adat Erau merupakan upacara adat yang paling meriah bagi masyarakat Suku Kutai.

Upacara adat Erau merupakan warisan tradisi di lingkungan Kesultanan Kutai Kartanegara Ing Martadipura. Semula upacara adat ini dilakukan untuk penobatan Raja atau Sultan, namun dalam perkembangannya upacara adat ini merupakan ungkapan rasa syukur atas hasil panen dan hasil bumi yang dinikmati rakyat. Pada masa kerajaan Kutai Kartanegara, upacara adat Erau dilakukan oleh kerabat kerajaan dengan mengundang pemuka masyarakat yang setia kepada Raja dan dilakukan selama tujuh hari tujuh malam yang terdiri dari beberapa tahapan, salah satunya adalah Bepelas.
Tarian yang dihadirkan saat ritual Bepelas salah satunya adalah Tari Dewa Memanah, yang merupakan tarian yang wajib ada dalam upacara ritual Bepelas. Tari ini dilakukan oleh seorang penari perempuan dengan properti busur panah dan panah yang bercabang tujuh. Tulisan ini akan mengungkapkan makna dan simbol yang terdapat dalam bentuk penyajian tari Dewa Memanah. Tujuannya adalah agar maknamakna dan simbol yang ada pada tarian tersebut dapat dipahami dan hubungannya dengan kepercayaan masyarakat suku Kutai.

Pendekatan yang digunakan dalam tulisan ini adalah kajian semiotika Pierce. Bagi Pierce tanda dan pemaknaan bukan merupakan sebuah struktur melainkan suatu proses yang berorientasi pada kemampuan berfikir yang mencakup kemampuan intelektual sampai pada kemampuan memecahkan masalah yang disebutnya semiosis. Proses semiosis ini melalui tiga tahap yaitu tahap pertama adalah penyerapan aspek representamen tanda melalui panca indra, kedua mengaitkan secara spontan dengan pengalaman dalam kognisi manusia yang memaknai representament itu (disebut object), dan ketiga menafsirkan object sesuai dengan keinginanya, tahap ketiga ini disebut interpretant. Cara pemaknaan tanda melalui kaitan antara representamen dan object didasari oleh pemikiran bahwa object tidak selalu sama dengan realitas yang diberikan 
oleh representamen. Object timbul karena pengalaman memberi makna pada tanda. (Hoed, 2014: 8-9)

\section{PEMBAHASAN}

\section{A. Bentuk Penyajian Tari Dewa Memanah}

Jecqueline Smith dalam Ben Suharto menyatakan bahwa tari bertujuan untuk mengkomunikasikan gagasan dan oleh karena itu begitu banyak hal terdapat dalam tari itu lebih dari hanya sekedar rangkaian gerak. Tari memiliki bentuk, wujud keseluruhan sistem, kesatuan ciri atau mode, apa yang terlihat sebagai rangkaian ini terdiri dari komponenkomponen. Adapun komponen yang terdapat dalam tari Dewa Memanah yang terdiri dari tema, gerak, penari, iringan, properti, desain lantai, tempat pertunjukan, dan waktu pertunjukan.

\section{Tema}

Tema tari dapat dipahami sebagai pokok permasalahan yang mengandung isi atau makna tertentu dari sebuah koreografi, melalui tema maka tiap-tiap gerak yang dilakukan mengandung maksud dan ekspresi tertentu. Dalam sebuah tarian, apa saja dapat dijadikan tema misalnya kejadian sehari-hari, pengalaman hidup yang sederhana, cerita rakyat, cerita kepahlawanan, legenda, upacara agama dan lain-lain dapat menjadi sumber tema.
Tema dalam tari Dewa Memanah sangat jelas terlihat tentang penggambaran seorang dewa yang sedang memanah dengan maksud untuk mengusir roh-roh jahat agar tercipta ketentraman, keselamatan, dan keamanan selama prosesi ritual Bepelas berlangsung.

\section{Gerak}

Elemen yang paling baku dalam sebuah tari adalah gerak. Gerak merupakan pengalaman fisik yang paling elementer dari kehidupan manusia. Gerak merupakan media bagi manusia untuk menyatakan keinginannya, atau dapat dikatakan pula bahwa gerak merupakan bentuk refleksi spontan dari gerak batin manusia.

Gerakan tari Dewa Memanah pada dasarnya mengikuti ketukan-ketukan irama yang mengiringinya, di mana gerakannya cenderung lembut dan mengalun. Gerak yang ditampilkan merupakan bentuk eksplorasi dan interpretasi tentang simbol dari karakter Dewa yang berkaitan dengan fungsi tarian ini. Oleh karena itu gerakan tari Dewa memanah didominasi pada gerakan kaki, tangan, dan gerakan kepala.

Gerak kepala seperti mengadah dan menunduk merupakan ekspresi sesuai karakter Dewa yang sedang berfokus melihat atas dan bawah untuk membidik sasaran ketika memanah. Begitu pula dengan gerakan tangan dan kaki, penari 
bergerak tegas pada gerakan mengayunkan tangan serta hentakkan pada kaki.

\section{Pada gerak tari Dewa Memanah} terdapat unsur gerak tari Jawa di dalamnya. Masuknya unsur gerak tari Jawa pada tarian Dewa Memanah dipengaruhi oleh adanya akulturasi antara kebudayaan Kutai dan Jawa yang berbaur sejak berinteraksinya kerajaan Kutai Kartanegara dengan kerjaan Majapahit pada zaman dahulu sekitar tahun 1370-1420 M. Akibat interaksi dan hubungan tersebut, kebudayaan yang berasal dari kerajaan Majapahit masuk dan berbaur dengan kebudayaan Kutai, salah satunya adalah seni tari.

\section{Penari}

Penari merupakan hal yang terpenting dalam sebuah pertunjukan tari, karena penari adalah pelaku yang akan menunjukkan apa yang ingin disampaikan melalui gerak.

Pelaksanaan tari Dewa Memanah pada acara Bapelas ditarikan oleh penari tunggal perempuan yang mengelilingi Tiang Ayu sebagai bentuk perlindungan agar terhindar dari segala macam marabahaya dan ritual Bepelas berjalan lancar tanpa ada gangguan. Penari Dewa Memanah haruslah seorang perempuan yang berasal dari desa Kedang Ipil. Hal ini sudah secara turuntemurun dilakukan dan dipercayai oleh pihak Keraton Kutai Kartanegara pada setiap upacara adat Erau.

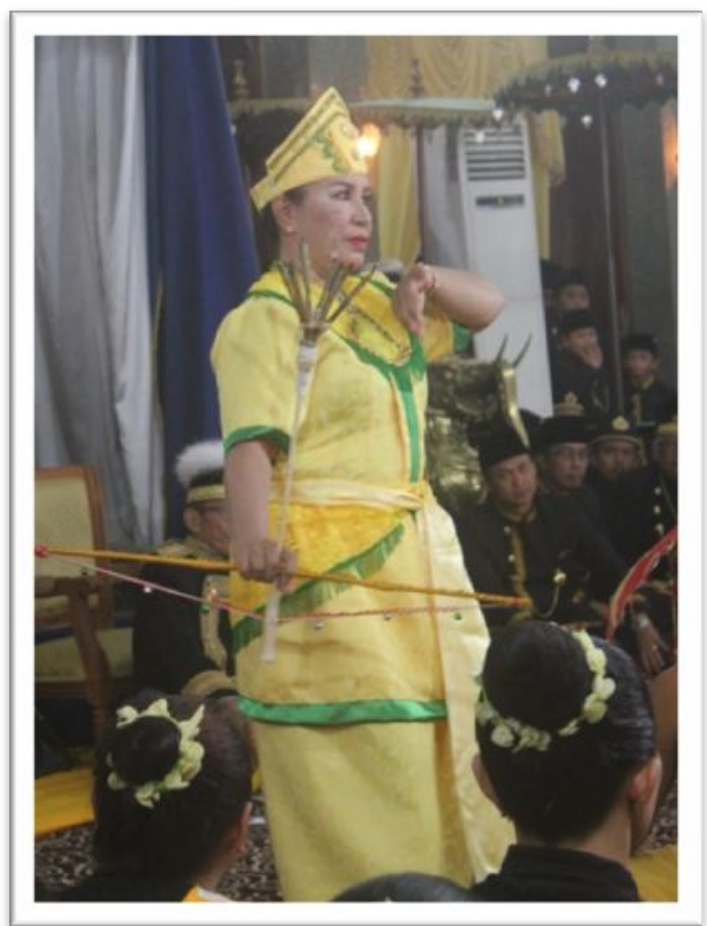

Gambar 1. Penari Tari Dewa Memanah (Dokumentasi, Aulia, 2016)

\section{Iringan}

Iringan tari dapat menciptakan suasana karena memiliki unsur ritme, nada, melodi, dan harmoni, sehingga dapat menimbulkan kualitas emosional yang dapat menciptakan suasana rasa sesuai yang dibutuhkan di dalam sebuah tarian. Iringan dalam tari adalah suatu pola ritmis yang dapat memberikan makna, struktur, dinamika, serta kekuatan gerak tari. Gerak tanpa iringan rasanya tidak lengkap. Dalam tari, iringan dapat hadir dengan bentuk yang eksternal ataupun internal. Dalam bentuk eksternal iringan hadir dari luar diri penari, 
sedangkan internal iringan datang dari tubuh penari misalnya dengan tepukan, vokal, dan sebagainya.

Alat musik yang digunakan untuk mengiringi tari Dewa Memanah berupa seperangkat instrumen gamelan. Laras yang digunakan untuk mengiringi tari Dewa Memanah adalah Laras Slendro. Iringan dalam tari Dewa Memanah merupakan partner gerak yang kehadirannya dalam tari tidak hanya mengiringi, namun juga memiliki karakter untuk dapat mengekspresikan maksud dari tarian. Ritme musik tari Dewa Memanah relatif monoton tetapi memiliki struktur yang dapat memberikan makna serta kekuatan magis dalam gerak sebagai persembahan kepada roh leluhur dan dewa agar melimpahkan kesejahteraan bagi masyarakat.

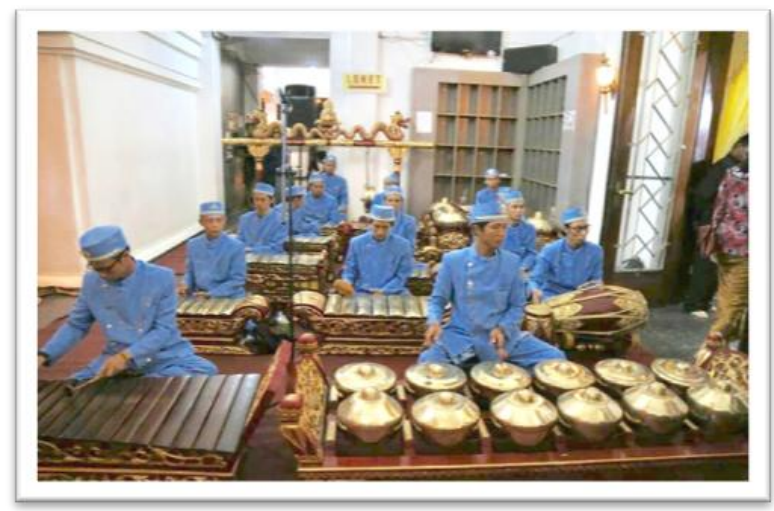

Gambar 2. Seperangkat gamelan yang mengiringi tari Dewa Memanah

(Dokumentasi. Nurmi, 2016)

Instrumen gamelan yang dimainkan bersama oleh pemusik juga bertujuan untuk mengundang dewa-dewa yang berasal dari sungai dan alam semesta yang mereka tempati. Pada prinsipnya pelaksanaan tari Dewa Memanah adalah menjaga serta meminta kekuatan dan perlindungan.

\section{PolaLantai}

Pola lantai yang dilalui oleh penari Dewa Memanah menggunakan garis lurus pada setiap sisi dari arena pentas. Pola yang dilalui sang penari adalah mengitari Tiang Ayu, yang merupakan area tempat dilaksanakannya ritual Bepelas. Pola lantai tersebut bertujuan untuk menjaga Tiang Ayu dan area Bepelas agar bersih dari segala hal negatif dan gangguan roh jahat yang ingin merusak jalannya prosesi ritual Bepelas, sehingga membawa ketentraman, keamanan dan keselamatan bagi Sultan dan masyarakat suku Kutai.

\section{Rias dan Busana}

Busana merupakan segala macam benda yang melekat pada tubuh penari. Berfungsi sebagai penutup tubuh dan memperindah seseorang dalam tampilannya. Tata rias dan busana dalam seni tradisi masih memiliki fungsi yang sangat penting. Kehadirannya dalam sebuah pertunjukan tari secara umum dapat memperkuat ekspresi, penokohan, serta keindahan. Selain itu juga dapat memberikan gambaran peristiwa di atas 
panggung tentang siapa, kapan, dan di mana peristiwa yang digambarkan dalam pertunjukan itu terjadi. Begitu besar arti sebuah busana sehingga dapat pula digunakan sebagai sebuah simbol dalam masyarakat. Hal tersebut diungkapkan bahwa "ucapan manusia, gerakan tubuh benda yang digunakan, warna, hingga pola yang melekat pada pakaian dapat menjadi simbol yang berlaku pada suatu kelompok entitas manusia bersangkutan.

Tata rias yang digunakan pada tari Dewa Memanah adalah rias korektif yaitu, rias cantik. Rambut disisir rapi lalu dijepit sebelah kanan dan kirinya, setelah itu menggunakan irah-irahan berbentuk segitiga yang berwarna kuning agar terlihat indah.

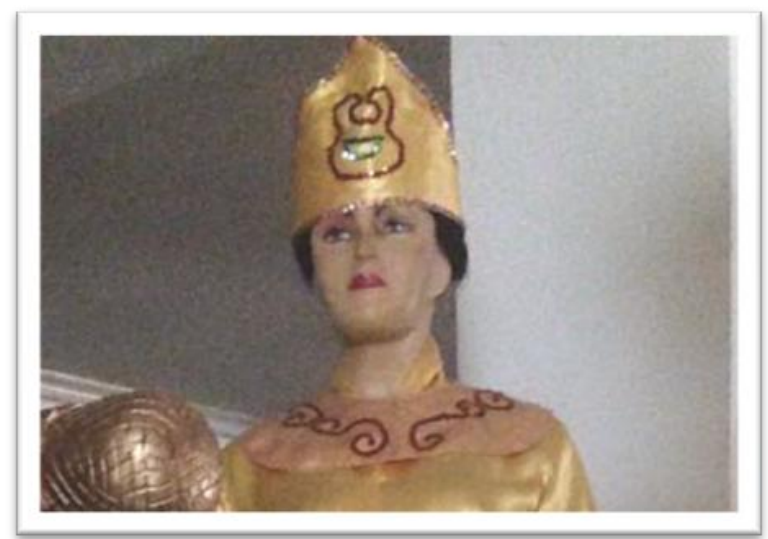

Gambar 3. Tata rias dan model kepala pada tari Dewa Memanah

(Dokumentasi. Dery, 2017)

\section{Dalam menarikan tari Dewa} Memanah, penari menggunakan busana berupa blouse, rok panjang, serta selendang yang diikatkan pada pinggang dan seluruhnya terbuat dari kain berwarna kuning. Terdapat less berwana biru pada bagian bawah lengan, bawah baju, dan bawah rok. Penari juga menggunakan leheran berupa kalung berbentuk segitiga berwarna kuning keorange-an pada bagian dada yang dikaitkan pada leher.

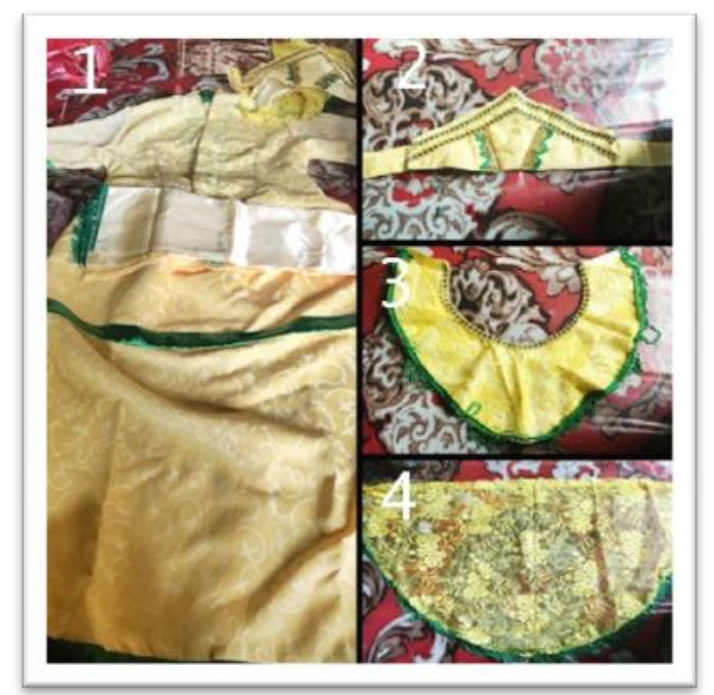

Gambar 4. Kelengkapan kostum tari Dewa Memanah (Dokumentasi, Aulia, 2017)

Keterangan gambar 4:

1. Blouse, ikat pinggang, dan rok

2. Ikat kepala (irah-irahan)

3. Leheran

4. Selembar kain yang diikatkan pada pinggang

\section{Properti}

Setiap peran penari memiliki properti tari yang berbeda. Properti yang digunakan untuk kelengkapan tambahan menjadi bagian tersendiri dari seni pertunjukan tari. Properti tari merupakan alat yang dimainkan oleh penari di atas 
panggung (arena pentas) yang memiliki kegunaan untuk menciptakan suasana sekitar untuk ditampilkan menjadi suatu gambaran tentang ciri khas suatu tarian. Kehadiran properti biasanya digunakan untuk membantu memperjelas karakter peristiwa, ruang, atau bahkan memamerkan ketrampilan teknik dari para penari di atas panggung.

Pada tari Dewa Memanah, penari menggunakan busur dan anak panah bercabang tujuh. Busur dan anak panah yang digunakan tidak terlalu besar sehingga memudahkan sang penari saat membawa dan memainkannya.

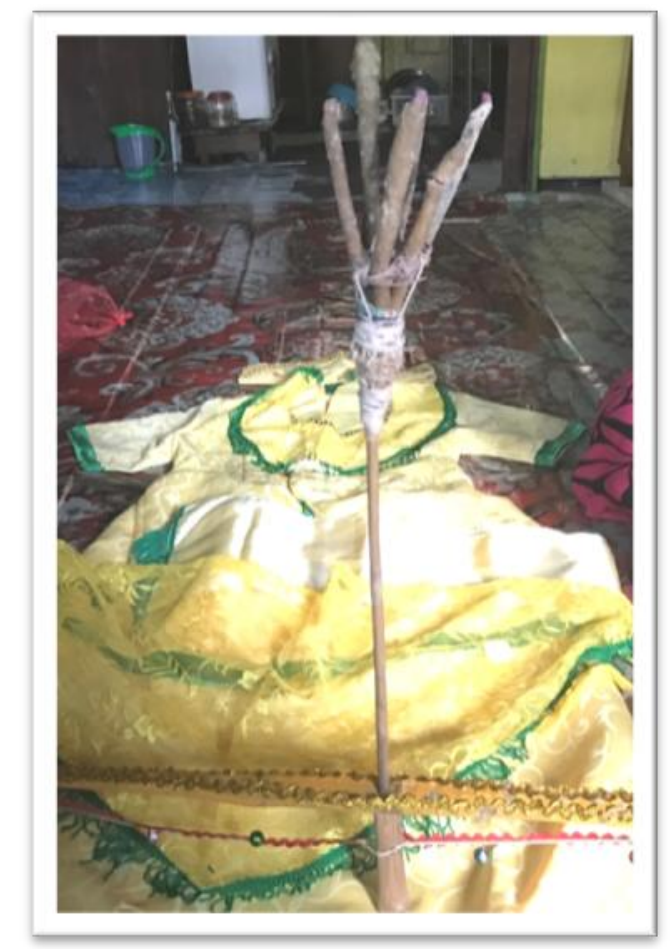

Gambar 5. Properti panah tari Dewa Memanah (Dokumentasi, Aulia, 2017)

\section{Tempat dan Waktu Pelaksanaan}

Pada sebuah pertunjukan atau pementasan suatu bentuk kesenian, baik seni drama, seni tari, seni musik, maupun rupa selalu memerlukan suatu tempat atau ruangan. Pada dasarnya ada tiga jenis arena pentas yang paling banyak dikenal di Indonesia, yakni panggung proscenium, pendapa, dan arena terbuka. Pangung proscenium adalah panggung yang berbingkai, di sisi samping terdapat wing dan di bagian atas ada teaser. Bentuk panggung ini dulunya dibawa orang-orang Belanda ketika hendak mementaskan tonil di Indonesia. Jenis panggung ini sampai kini banyak dimiliki oleh lembaga-lembaga kesenian. Pendapa merupakan arena pertunjukan di Jawa yang biasanya digunakan untuk seni pertunjukan di istana. Cirinya adalah tiang penyangga bangunan yang sering disebut saka. Pendapa banyak dimiliki oleh lembaga-lembaga pemerintah di Jawa dari Lurah hingga Gubernur. Bentuk terbuka atau arena adalah tempat pentas yang meniadakan batas pemisah antara pemeran dengan penonton. Daerah pemain di tengah dan penonton berada disekelilingnya. Bentuk panggung ini tidak memiliki batas antara pemain atau pemeran dan penonton hampir tidak memiliki batas, serta tidak memerlukan pelayanan yang khusus, misalnya menggunakan skeneri yang realistis tiap pergantian adegan. Arena tebuka adalah panggung atau arena 
pertunjukan yang bentuknya terbuka tanpa diberi atap. Jenis arena ini memiliki bentuk yang beragam, bisa berupa tanah lapang, atau panggung yang dibuat terbuka berada di tengah lapang, dan sebagainya.

Tari Dewa Memanah ditampilkan di arena Keraton Kesultanan Kutai Kartanegara yang tertutup dan merupakan tempat ritual Bepelas berlangsung. Tarian ini ditarikan di sekitar Tiang Ayu yang berada tepat di depan singgasana Sultan.Tari Dewa Memanah dalam upacara adat Erau hanya ditampilkan pada upacara Bepelas dan tidak boleh ditampilkan apabila belum waktunya. Tarian ini pun hanya boleh ditampilkan di dalam Keraton Kutai Kartanegara dan tidak boleh ditarikan di luar lingkungan Keraton. Hal ini dikarenakan Tarian Dewa Memanah merupakan tarian yang disakralkan bagi masyarakat Kutai. Tari Dewa Memanah yang ditampilkan pada ritual Bepelas diselenggarakan pada malam hari selama tujuh hari tujuh malam kecuali pada malam jum'at.

\section{B. Makna dan Simbol Tari Dewa Memanah dalam Upacara Adat Erau}

Simbol merupakan alat yang kuat untuk memperluas pengetahuan kita, merangsang daya imajinasi kita, dan memperdalam pemahaman kita. Sebuah simbol dapat dipandang sebagai sebuah objek yang menggambarkan atau menandakan sesuatu yang lebih besar dan tinggi berkaitan dengan sebuah makna, realitas, suatu cita- cita, nilai, presentasi, kepercayaan, masyarakat, konsep, lembaga, dan suatu keadaan.

\section{Makna dan Simbol Gerak Tari Dewa}

\section{Memanah}

Tari Dewa Memanah yang erat kaitannya dengan ritual kepercayaan ini tercipta sebagai ritual untuk mengusir rohroh jahat serta permohonan kepada Dewa agar diberi keselamatan, terutama pada prosesi ritual Bepelas berjalan lancar dan aman.

Tarian tersebut memiliki simbol berupa perjuangan yang menggambarkan karakter Dewa yang tangguh dalam menjaga area tempat dilaksanakannya ritual Bepelas. Dalam tarian Dewa Memanah, menggambarkan sesosok Dewa menari sambil memanah. Gerakan memanah tersebut diarahkan ke empat penjuru mengikuti arah mata angin. Adapun tujuan anak panah tersebut ditujukan antara lain:

a. Pertama, menuju ke arah ulu sungai.

b. Kedua, menuju ke arah muara sungai.

c. Ketiga, menuju ke arah matahari terbit. 
d. Keempat, menuju ke arah matahari terbenam.

Keempat tempat tersebut dipercaya oleh masyarakat suku Kutai sebagai pusat dari kekuatan gaib. Makna dari tarian tersebut adalah menjaga alam semesta tempat mereka tinggal agar bersih dari segala gangguan roh jahat yang dapat merusak kehidupan bermasyarakat maupun ekonomi mereka.

Jenis tanda yang hadir pada proses analisis pemaknaan gerak dari Tari Dewa Memanah tersebut adalah berupa iconik. Dilihat dari proses pola gerak Tari Dewa Memanah (R) yang mengalun namun tegas sambil membawa busur dan anak panah (O), hadirin dan masyarakat menafsirkan bahwa Dewa sedang berjaga (berpatroli) siap untuk berperang (I). Proses pemaknaan ini memiliki sifat kemiripan sebagaimana telah ada wujud nyatanya. Proses pemaknaan tersebut tidak berhenti di situ, karena hasil penasfsiran tersebut masih dapat berlanjut yaitu, dari hasil pemaknaan antara (R) dan (O) yang berupa Interpretan (I) dapat memunculkan Representamen $(\mathbf{R})$ yang baru sebagai sesuatu yangg bersifat unlimited. Dapat dijelaskan hasil dari pengamatan tari Dewa Memanah menimbulkan penafsiran yang iconik, berupa Dewa yang sedang berjaga (R) mengelilingi area Bepelas (O). Area bapelas merupakan interpretasi iconik yang berupa penyederhanaan dari wilayah tempat tinggal masyarakat suku Kutai yang akan dijaga dari segala gangguan roh jahat. Dapat diartikan bahwa Tari Dewa Memanah merupakan simbol dari sebuah perjuangan yang memiliki makna keselamatan bagi masyarakat suku Kutai.

\section{Makna dan Simbol Iringan Tari Dewa} Memanah

Tarian Dewa Memanah diiringi oleh musik gamelan dengan menggunakan laras slendro. Gamelan merupakan ensembel musik yang biasanya menonjolkan metalofon, gambang, gendang, dan gong. Istilah gamelan merujuk pada instrumennya yang merupakan satu kesatuan utuh yang diwujudkan dan dibunyikan bersama.

Gamelan memiliki nilai spiritual dan segala hal yang berhubungan dengan mistis misalnya perlunya membuat sesaji sebelum pementasan, larangan melangkahi perangkat gamelan, ataupun perlunya memandikan gamelan dalam waktu-waktu tertentu tidak hanya membutuhkan rasionalisasi, namun juga normalisasi persepsi.

Terdapat dua jenis tanda pada bagian analisis ini yaitu, simbolik, iconik, dan indeksikal. Gamelan (R) merupakan 
salah satu pusaka Keraton Kutai Kartanegara bagi masyarakat Kutai dalam bentuk instrumen musik yang menghasilkan bunyi (O) sebagai sarana pengiring pertunjukan. Bunyi yang dihasilkan dari gamelan tersebut bertujuan untuk mendatangkan elemen-elemen positif (roh para leluhur dan Dewa bumi), serta mengusir atau menjauhkan elemen-elemen negatif (roh jahat, hantu Raja Nyahu ${ }^{1}$ ) (I). Pada proses pemaknaan tersebut masuk kedalam jenis simbolik, karena bersifat mewakili sebuah hal yang lebih besar yang ada dibalik bunyi gamelan itu sendiri.

Gamelan yang ada di Kutai Kartanegara sekilas mata tampak sama dengan gamelan pada umumnya yang berasal dari tanah Jawa, tetapi apabila ditelusuri lebih lanjut, gamelan Kutai memiliki warna dan pola yang berbeda, serta nafas permainan yang sangat terlihat nyata perbedaannya. Secara iconik gamelan Kutai dapat diidentifikasi melalui bentuk penyajian serta komposisi pola permainannya.

\section{Analisis secara indeksikal,} digunakannya gamelan sebagai musik pengiring tari Dewa Memanah menurut penulis disebabkan oleh kesamaan makna antara bunyi yang dihasilkan oleh gamelan

${ }^{1}$ Hantu Raja Nyahu merupakan roh jahat yang di percaya masyarakat suku Kutai suka mengganggu kehidupan dan membuat dunia menjadi gelap (menimbulkan bencana). dan gerakan tari Dewa Memanah yang sama-sama memiliki maksud dan tujuan untuk mendatangkan hal positif dan mengusir hal-hal negatif untuk menciptakan ketentraman dalam kehidupan, khususnya untuk masyarakat suku Kutai.

\section{Makna dan Simbol Rias dan Busana}

\section{Tari Dewa Memanah}

Penari pada saat menarikan tari Dewa Memanah (R) menggunakan kostum yang berwarna kuning (O). Dalam psikologi warna kuning mempunyai makna prestasi, kesuksesan, kemewahan, kemenangan dan juga kemakmuran. Dalam agama Hindu warna kuning merupakan warna keramat dan dianggap warna kesucian di alam gaib sehingga hal-hal yang berbau gaib selalu dihubungkan dengan kain kuning (I). Apa yang terungkap dalam konsep psikologi dan agama Hindu ini tanda yang diartikan masuk ke dalam jenis tanda yang berupa simbolik, karena maknanya telah disepakati oleh masyarakat dan berlaku secara universal. Bagi masyarakat suku Kutai sendiri, warna kuning merupakan sebuah identitas adat di Kesultanan Kutai yang dipercaya sebagai alat untuk menjaga diri. Makna dari warna kuning tersebut melambangkan keagungan bagi masyarakat suku Kutai. 
Arti warna kuning itu sendiri melambangkan identitas adat di Kesultanan Kutai Kartanegara. Kain kuning adalah simbol yang dipercaya untuk menjaga diri, menjaga tempat tempat sakral, pengikat benda pusaka, dan lain-lain. Jadi bagi masyarakat Kutai (R) kain kuning (O) sebagai kain yang disakralkan dalam setiap kegiatan apapun yang dilakukan termasuk upacara adat (I). Pada proses pemaknaan tanda bagian ini, tanda digolongkan ke dalam jenis iconik. Hal ini dikarenakan (R) dan (O) berada dalam kognisi budaya yang bersangkutan serta hubungan antara $(\mathbf{R})$ dan (O) merujuk pada suatu identitas yaitu, suku Kutai.

Kesederhanaan kostum dan rias yang digunakan pada tarian tersebut merupakan simbol dari kesederhanaan masyarakat suku Kutai. Bentuk ikat kepala (R) yang berbentuk segitiga menuju ke atas (O) memiliki makna bahwa setiap yang dilakukan dan segala yang ada di dunia ini akan selalu kembali kepada penguasa alam semesta yaitu, Tuhan (I). Tuhan dalam pengertian kepercayaan masyarakat suku Kutai adalah berupa Dewa, dan di bawah Dewa adalah berupa roh para leluhur yang dapat memberi kekuatan dan restu bagi kehidupan masyarakat suku Kutai.

\section{Makna dan Simbol Properti Tari Dewa} Memanah

Properti yang digunakan pada tari Dewa Memanah, yaitu busur dan anak panah dengan ujung berapi. Panah adalah salah satu perlambangan senjata yang sering digunakan untuk melumpuhkan lawan saat berperang pada zaman dahulu. Busur merupakan alat untuk melesatkan anak panah agar sampai kepada tujuan. Proses pemaknaan pada properti Tari Dewa Memanah menggunakan jenis tanda berupa simbolik karena hubungan (R) dan (O) memiliki sifat yang konvensional. Pada tarian Dewa Memanah (R) anak panah dengan ujung berapi (O) tersebut ditujukan untuk mengusir roh jahat serta membumihanguskan segala hal negatif dan juga sebagai bentuk pengharapan pada Dewa Bumi agar memberi keselamatan pada bumi tempat mereka tinggal sehingga nantinya akan membawa kesejahteraan (I).

Pada tari Dewa Memanah (R) anak panah yang bercabang tujuh (O) menyimbolkan waktu lama berperang (I). Hal ini telihat dari banyaknya ujung panah yang dinyalakan dengan api pada setiap harinya. Pada hari pertama hanya satu cabang panah berapi yang dinyalakan dan seterusnya dihari berikutnya. Mengambil kesimpulan dari cerita orang tua zaman dulu, busur dan anak panah tersebut 
merupakan sebuah simbolisasi dari senjata yang digunakan untuk berperang saat berjuang mengusir dan membunuh Raja Nyahu. Raja Nyahu ini merupakan roh jahat yang mengganggu kehidupan masyarakat suku Kutai. Proses analisis ini digolongkan pada jenis tanda berupa iconik, di mana anak panah yang bercabang tujuh tersebut merupakan suatu penyederhanaan dari waktu lamanya berperang dalam mengusir hantu Raja Nyahu.

\section{Makna dan Simbol Pola Lantai Tari} Dewa Memanah

Penari Dewa Memanah mengelilingi arena pentas sebanyak dua kali. Dahulunya, tarian ini (R) dilakukan dengan empat kali putaran (O), di mana setiap putaran tersebut mewakili satu daerah yang dianggap sakral dan merupakan pusat dari segala kekuatan gaib yang dipercaya oleh masyarakat suku Kutai (I). Tujuannya adalah untuk mengundang para roh leluhur untuk ikut serta datang dan menjaga lingkungan selama ritual Bepelas berlangsung. Pada putaran pertama menunjukkan bahwa Dewa menari menuju ke wilayah Kelurahan Mangkurawang. Pada putaran kedua penari menuju ke depan Keraton Kutai Kartanegara sebagai titik tengah dari lokasi Kesultanan Kutai Kartanegara. Kemudian saat putaran yang ketiga merupakan sebuah simbolisasi Dewa menuju ke tepian sungai Mahakam. Terakhir, Dewa digambarkan menuju ke arah kecamatan Anggana, di mana merupakan lokasi pusat pemerintahan pertama Kerajaan Kutai Kartanegara. Maknanya adalah untuk mengundang para roh leluhur untuk ikut serta datang dan menjaga lingkungan selama ritual Bepelas berlangsung. Jenis tanda yang berlaku pada proses pemaknaan tersebut adalan berupa iconik di mana, hubungan (R) dan (O) bersifat ilustratif dan penyederhanaan.

Saat ini, dalam tarian Dewa Memanah (R) penari melakukan putaran sebanyak dua kali (O) saja di mana pada putaran pertama maknanya untuk memanggil Dewa dan penghuni alam semesta untuk ikut dalam acara yang sedang diselenggarakan, ini berarti tamu yang diundang berasal dari seluruh alam tanpa terkecuali. Putaran kedua untuk mengusir segala hal buruk dan roh-roh jahat yang ada di sekitar tempat dilaksanakanya acara tujuannya untuk melindungi tamu yang sudah diundang dan hadir dari gangguan roh jahat dan hal-hal yang negatif lainya (I). Dari nilai ritual yang dilaksanakan dengan baik dipercaya akan memberikan dampak positif dalam kehidupan masyarakat. 
6. Makna dan Simbol Tempat dan Waktu Pertunjukan Tari Dewa Memanah

Tari Dewa Memanah (R) hanya dilaksanakan di depan singgasana sultan dan di sekitar Tiang Ayu yang berada di dalam Keraton Kutai Kartanegara (O). Tiang Ayu yang dipercaya sebagai raga sang Sultan. Bagi masyarakat suku Kutai, menjadi salah satu alasan mengapa tarian tersebut ditarikan di sana. Maknanya adalah sebagai raga sang Sultan harus selalu dijaga dan dilindungi dari segala macam marabahaya dan gangguan dari luar sebagai pengabdian seorang prajurit terhadap sang Sultan (I), oleh karena itu tarian ini ditarikan di sekitar Tiang Ayu. Pada proses pemaknaan di atas jenis tanda yang hadir dapat digolongkan pada jenis tanda yang berupa indeksikal karena hubungan (R) dan (O) memiliki hubungan yang berupa sebab akibat.

Proses pemaknaan berlanjut pada simbol yang digambarkan dalam tempat pertunjukkan (R) tersebut adalah bumi sebagai alam semesta (O) merupakan tempat berkumpulnya manusia dan segala kekuatan yang ada seperti, makhluk gaib, roh para leluhur, dewa, dan lain-lain harus selalu dijaga agar kehidupan manusia berjalan dengan lancar, tentram, aman, dan tenang (I). Proses pemaknaan di atas tersebut berupa iconik karena berada di

dalam kognisi masyarakat yang
bersangkutan serta budaya yang
menyepakati.

Tari Dewa Memanah (R) diselenggaran setiap malam selama upacara adat Erau dilaksanakan yaitu tujuh hari tujuh malam, tepatnya sebelum ritual bepelas dimulai (O). Selama tujuh hari tujuh malam ini digambarkan bahwa Dewa sebagai prajurit dari istana berusaha melawan hantu Raja Nyahu yang menggangu dan membuat alam semesta yang gelap ini menjadi terang, tentram, dan aman (I). Sehingga masyarakat dapat kembali beraktivitas dan Sultan melaksanakan prosesi ritual berikutnya. Proses pemaknaan ini menggunakan jenis tanda yang berupa iconik yaitu, hubungan (R) dan (O) bersifat ilistratif karena merupakan sebuah gambaran kejadian yang sebenarnya. Tari ini memiliki simbol bahwa masyarakat suku Kutai merupakan masyarakat yang pantang menyerah dan terus berjuang untuk mendapatkan kesejahteraan dan keselamatan bagi sesama. Maknanya adalah setiap tujuan memiliki tantangan dan tekad yang besar untuk mecapai tujuan dan cita-cita yang diinginkan. 


\section{III.PENUTUP}

Dari hasil pembahasan yang telah dipaparkan, maka dapat ditarik beberapa kesimpulan, yaitu Tari Dewa Memanah merupakan tarian sakral dalam upacara ritual Bepelas Sultan yang dilaksanakan di Keraton Kutai Kartanegara. Pelaksanaan tari Dewa Memanah adalah simbol membersihkan serta meminta perlindungan, ketentraman, dan keselamatan bagi masyarakat suku Kutai. Ragam gerak tari Dewa Memanah selain bertujuan untuk mengusir roh-roh jahat, juga melambangkan pengharapan dengan memanggil roh-roh para leluhur untuk mengikuti upacara yang sedang dilaksanakan dan memberikan keselamatan bagi kehidupan dunia Sultan maupun masyarakat suku Kutai.

Busana yang menggunakan pakaian berwarna kuning sebagai simbol yang dipercaya untuk menjaga diri, menjaga tempat tempat sakral, pengikat benda pusaka, yang dikaitkan dengan kehidupan manusia agar selalu terjaga dan terhindar dari segala gangguan roh jahat dan marabahaya. Makna dari warna kuning tersebut melambangkan keagungan bagi masyarakat suku Kutai. Properti tari Dewa Memanah melambangkan kekuatan senjata yang digunakan untuk mengusir roh-roh jahat dalam upacara dan sebagai bentuk senjata yang membantu melindungi kehidupan manusia.
Bagi masyarakat suku Kutai, tarian ini menggambarkan hubungan manusia dan alam lingkungan sekitarnya, manusia dengan rohroh leluhur, serta mencerminkan kehidupan sosial masyarakat yaitu sikap penghormatan terhadap nilai-nilai kehidupan yang diajarkan para leluhur yang telah menjaga dan melindungi masyarakat, nilai kebersamaan, nilai kekeluargaan dan tanggung jawab sangat dijunjung tinggi oleh masyarakat. 


\section{DAFTAR SUMBER ACUAN}

\section{A. Sumber Tercetak}

Dillistone, F. W. 2002. ThePowerofSymbols, terj. A. Widyamartaya, Daya Kekuatan Simbol. Yogyakarta: Kanisius.

Ellfeldt, Lois. 1977. A Primer For Choreographers, terj. Sal Murgiyanto, Pedoman Dasar Penata Tari, Jakarta: Lembaga Pendidikan Kesenian Jakarta.

Hadi, Y. Sumandiyo. 2011. Koreografi Bentuk-Teknik-Isi.Yogyakarta: Cipta Media.

Hoed, Benny H. 2014. Semiotik dan Dinamika Sosial Budaya. Depok: Komunitas Bambu.

Kasmahidayat, Yuliawan. 2012. ApresiasiSimboldalamSeniNusantara. Bandung: CV. BintangWarliArtika.

Smith, Jacqueline. 1985. Komposisi Tari: Sebuah Petunjuk Praktis Bagi Guru, terj. Ben Suharto. Yogyakarta: Ikalasti.

Soedarsono, R.M. 1978.

PengantarPengetahuandanKomposisiTa ri. Yogyakarta: ASTI.

\section{B. Narasumber}

Hamtiah

Sebagai: Ketua Dewa dalam upacara adat Erau

HRM. Saidar SE. MM.

Sebagai : Kasi pengembangan dan Pembinaan Kesenian Disbudpar KuTai Kartanegara

Kuspawansyah.

Sebagai: Kepala Desa Kedang Ipil

Murad.

Sebagai: Sekretaris Desa Kedang Ipil

Rohanah

Sebagai: Penari tari Dewa Memanah
Tajudi.

Sebagai: Masyarakat desa Kedang Ipil yang di tetuakan (Belian) 